\title{
Aestheticizing Violence: Paul Bowles' Prolific Partnership with His Motiveless Villain in The Delicate Prey
}

\author{
Sina Movaghati \\ Doctoral Candidate at the Heidelberg Center for American Studies, Heidelberg University, \\ Germany. ORCID ID: oooo-0oo3-3433-2487. \\ Email: sina.movaghati@as.uni-heidelberg.de
}

\begin{abstract}
:
Many critics have regarded the violence in Bowles as "meaningless" or "motiveless." By defining the connection between motive and act, this article tackles the indefinite nature of violence in Paul Bowles' collection of short stories, The Delicate Prey. To this end, a study of the typical Arab character in Bowles is offered. Also, the motive behind Bowles' villain is defined in the light of Samuel Taylor Coleridge's term "motiveless malignity." It is discussed that the contextless violence of Bowles has an estrangement effect on the victim; and his detached narration technique, together with the excessive occurrences of violence, leads to an aesthetic experience on the reader. "Aesthetic experience" is explained based on Slobodan Marković's definition of the term. It is concluded that Bowles' maneuvers over the subject of violence should be viewed in the light of a modernist aesthetic tradition based on violence rather than praxeological humanistic chain reactions.
\end{abstract}

Keywords: Paul Bowles; The Delicate Prey; motiveless violence; aesthetic experience

\subsection{Introduction}

Paul Bowles' fictional world is often described as perilous, bleak, and comfortless. One of the recurrent themes of Bowles' narrative is about the Americans who encounter unknown forces in the deserts of North Africa. "These forces may be internal, the repressed areas of [the westerners'] own psyche, or external, in alien peoples or hostile landscapes" (Pounds, 1981, p.620). Wendy Lesser states that Bowles derives his subject matter somewhere in the midst of the clash between the west and the east, as "most of his fiction deals with the meeting between [the] untamed parts of the world and the rigid expectations of Europeans and Americans" (Lesser, 1986, p.402). Even though Lesser's interpretation is correct, it only encompasses a certain type of Bowles' tales and leaves out the second type: a type that solely deals with the local inhabitants of North Africa. In some instances like "A Thousand Days for Mokhtar," "By the Water," and "A Distant Episode," one can hardly notice the influence of the colonizers on the lives of the indigenous dwellers. However, a motif that is relevant to both types is violence. By studying and focusing on the Arab characters of Bowles, I will inspect the subject of violence in Bowles' collection of short stories entitled The Delicate Prey and Other Stories to discuss several aspects of Bowles' violence, and examine whether or not Bowles' cold and detached depiction of violence can serve any particular purpose?

\footnotetext{
(C) AesthetixMS 2020. This Open Access article is published under a Creative Commons Attribution Non-Commercial 4.o International License (http://creativecommons.org/licenses/by-nc/4.o/), which permits non-commercial re-use, distribution, and reproduction in any medium, provided the original work is properly cited. For citation use the DOI. For commercial re-use, please contact editor@rupkatha.com.
} 


\subsection{The Violence in Bowles}

In a review published in The New Yorker in December 1950, Charles Jackson, who seemed unimpressed by The Delicate Prey, offered his opinions to the public: "For all their violence, these tales [The Delicate Prey] are actionless, which is to say characterless, and vice versa." Jackson concluded the review with a negative remark as well: "The inescapable fact remains that if the stories had truly been stories, if they had been engrossing, rich with life and meaning, the reviewer would have been absorbed and moved, and he would have learned and felt and believed"(Jackson, 1950, p.168). Even though Jackson's comments show his scrupulous reading of the stories, in my opinion, he arrived at an erroneous conclusion. Jackson mentions such elements as "violence," "characterless," "meaningless," and "lifeless" in a pejorative sense, however, in my estimation, these are the key components of Bowles' narrative that serve as advantages rather than demerits. In my reading, I offer an analysis of each term separately.

Perhaps the recurrence of violence in Bowles is so frequent that other critics also could not help but notice it as well. William Van O'Connor labels Bowles' violence as "meaningless" and states that Bowles' "characters are for the most part morally empty ... they desire some sense of being, but usually ... find it only in meaningless violence" (O'Connor, 1959, p.344). Ihab Hassan believes that the violence in Bowles emanates from pure irrationality and writes: "This 'Irrational thing' is key to the wanderers of Bowles, to their motive and act. For they are, in some part of their being, seekers without realizing why or what they seek" (Hassan, 1989, p.154). Walonen suggests that even though many of Bowles' stories take place in the post-war colonized Africa, they do not particularly "represent acts of native aggression against Westerners" (2011, p.37). So if the irrational violence observed in Bowles does not necessarily embody the natives' antagonism against the colonizers, what else could be the motive behind the acts of aggression? One of the rational doorways which may lead to the explanation of Bowles' subject of 'meaningless violence' is the study of his fictional characters and their motives behind the acts. To this end, I reckon "Mustapha and his Friends" can shed light on a certain type of character that the author encountered in North Africa. Prior to that, perhaps it would be better to discuss the term 'meaningless violence' in one of Bowles' short stories, "By the Water," to come to a better understanding of the nature of friction between the characters.

\subsection{By the Water: An Example of Meaningless Aggression}

"By the Water" is one of the stories included in the collection, and it is an excellent example of how a simple disagreement can easily flare up into a hostile situation. The story narrates the life of Amar, an indigenous Arab town-dweller of North Africa, who decides "to visit a neighboring city where his father had once told him some cousins lived" (By the Water, p.1). When Amar arrives in the nearby city, it "was already dark." The snow "was even deeper in the streets" of this new town, and the weather "was colder" than he had previously imagined. Amar finds this new place "unfriendly," and mutters under his breath, "a bad town."

Unable to find a proper place to spend the night, Amar abandons "the idea of trying to find his cousins before morning," and sets about looking for a local bathhouse "where he might sleep until daybreak" (p.2). At last, he comes to the success of finding a bath in the basement of a building where "the air was oppressively warm and moist" (p.2). Once Amar arrives at the bathhouse, he undresses and wonders "if his clothes would be molested during his absence" (p.3).

Then he wears "his money in a leather pouch which hung on a string about his neck" (p.3). Heading towards the water's edge naked, Amar turns around "to look once again at his clothing. 
No one seemed to have noticed him as he undressed. He [goes] on. It would not do to seem too distrustful. He would be embroiled immediately in a quarrel which could end badly for him" (p.3).

Bowles' third-person limited and subjective point of view divulges Amar's already-shaped notion of his fellow countrymen. Amar is very concerned due to the fact that he knows once the property falls into the hands of a stranger, the real owner might not have the chance to retrieve it, or it may be difficult for him to regain possession. At the same time, he is cautious about not revealing his distrust because a simple eye-contact with a stranger Arab may "immediately" lead to a "quarrel." Since Amar is alone and an outsider in this new town, he decides not to show his distrust and continues walking down to the pool. Amar descends the stoney stairs and reaches a dungeon-like bath with a pool placed in the middle. There, he confronts a small midget humanlike creature by the name of Lazrag, and the rest of the story continues as follows:

Suddenly a deep voice spoke close beside him [Amar]. He looked down as he heard it say: "Who are you?" The creature's head was large; its body was small and it had no legs or arms. The lower part of the trunk ended in two flipper-like pieces of flesh ... It was a man, and it was looking up at him from the floor where it rested.

"Who are you?" it said again, and its tone was unmistakably hostile.

Amar hesitated. "I came to bathe and sleep," he said at last.

"Who gave you permission?"

"The man at the entrance."

"Get out ..."

Amar was filled with anger. He looked down with scorn at the little being, and stepped away from it to join the men washing themselves by the water's edge. But more swiftly than he moved, it managed to throw itself along the floor until it was in front of him, when it raised itself again and spoke. "You think you can bathe when I tell you to get out?" It laughed shortly, a thin sound, but deep in pitch. Then it moved closer and pushed its head against Amar's legs. He [Amar] drew back his foot and kicked the head, not very hard, but with enough firmness to send the body off balance. (By the Water, P.4)

The rest of the narrative traces how Amar tries to elude Lazrag's bouncers. Even though the scene of the struggle between Amar and Lazrag may seem absurd or 'meaningless,' it helps us understand the characters' outlook on social interaction and their rationales behind the brawl. The most obvious thing which the passage reveals is that Amar and Lazrag do not use language as a means of negotiation or to reach a better understanding of the other (each other); the language they use is not an instrument for agreement and concord. It is rather exploited as a tool to oppress the other; even the word "compromise" may not exist in neither characters' mental lexicon.

Amar, who loses his temper quickly, is enraged at the creature and his immediate response is the feeling of 'scorn' towards the challenger because he does not see him as an equal being; Amar does not even try to resolve the situation by introducing himself or explaining about his current misfortune. He is well aware that if he shows any sign of weakness, it will not evoke the oppressor's sympathy; on the contrary, it puts Amar in a frail position to become subjugated by other men. Therefore, Amar comes up with the strategy to ignore Lazrag, which again is a sign of showing contempt for the other. It is evident that Amar is not a type of character who easily 
abandons the battle-ground by declamation and verbal threats; he can also overpower the opponent if he finds the chance.

Once it becomes evident that Lazrag's verbal attack does not work on the opposition, the creature quickly changes its oppressing strategy to a non-verbal abuse and uses its head-which is generally considered a place for thoughts, comprehension, and creativity-to physically oppress the other being. In this respect, perhaps violence is the only way that both Amar and Lazrag can think of because it has the capacity to resolve the dispute quickly. It is not peculiar that the critics consider such violence 'meaningless' or 'irrational' because violence in Bowles is not the last resort to put an end to a dispute; it is rather considered as a quick and available option to solve the issues. But, what is the inspiration behind such quick-tempered characters? And what is the model behind Bowles' typical North African Arab?

\subsection{Mustapha and His Friends}

As a twenty-year-old protégé of Gertrude Stein, Bowles was advised in 1931 to abandon Paris and travel to Morocco to pursue his career. He was told to disregard the two French coastal regions: "You don't want to go to Villefranche... Everybody's there. And St. Jean-de-Luz is empty and with an awful climate. The place you should go is Tangier" (Without Stopping, 2006, p.123). Despite the hardships he faced in Tangier (including typhoid fever that almost killed him), Bowles never left the city for good, and Tangier became a permanent home until his death in 1999.

In his autobiography, Without Stopping, Bowles writes about his first impressions of this mystic land: "Like any Romantic, I had always been vaguely certain that sometime during my life I should come to a magic place which in disclosing its secrets would give me wisdom and ecstasyperhaps even death" (Without Stopping, 2006, p.125). Later Bowles calls Tangier "a dream city" because the city could grant his most pressing wishes, which were "to be as far away as possible from New York" and at the same time, he could be in a place which was "the center of all existence" (Finlayson, 2015, p.91). Tangier of the 1930s, 40s, and 50s was a melting pot of the writers as diverse as Joe Orton, Tennessee Williams, Peter Orlovsky, Jean Genet, Jack Kerouac, William Burroughs, Allen Ginsberg, and many more. In the words of Edmund White, Tangier of those days had a reputation of "an affordable sin city" where "all of them [the artists] came for the boys and a few for the drugs, fewer still for the culture" (White, 2004, p.93). The city was balmy and sun-drenched throughout the year, and its exotic landscape drew the attention of many Americans and Europeans, but most importantly the cost of living was cheap compared to New York and Paris. So young Bowles enjoyed being in the company of the avant-garde artists, as well as benefiting from living in a cheap, exotic, and international environment. He reflects this in "Tea on the Mountain," a short story in the collection which he wrote in 1950: "The mail that morning had brought her a large advance from her publishers. At least, it looked large to her there in the International Zone where life was cheap" (Tea on the Mountain, p.128). However, Bowles did not remain in Tangier only because of its cheap living costs; he also found a type of character that could serve his fiction best. Moroccan culture became his source of inspiration and provided him with the materials that usually the critics associate with his name. He invented many of his typical characters out of his careful observations of certain Arab inhabitants of North Africa.

In Bowles' 1963 collection of travelogues entitled Their Heads Are Green and Their Hands Are Blue, there is a riveting chapter, "Mustapha and his Friends," which introduces Mustapha, "an illiterate city-dweller" of North Africa (Mustapha and his Friends, p.55). Even though it is often 
criticized for its dehumanizing nature, "Mustapha and his Friends" remained quite a significant piece as it defines the parameters of the type of fictional characters that frequently appear in The Delicate Prey. Bowles introduces Mustapha as a highly competitive individual trying to have the upper hand in his day-to-day affairs "even in friendship, love, marriage and family relationships"; in other words, he is driven by this goal that "he must be the victor" in every situation at all costs (p.57). Even though "Mustapha's behavior at any given moment is considerably more affected by the emotional factors" (p.61) and Bowles reckons that "logic is the last thing to look for in [his] behavior," (p.59), Mustapha is not totally devoid of rationales. He has a distinct philosophy of life and a specific set of values; for example, those "personal concepts as continence and honesty, such social virtues as a taste for the 'democratic way of life' and a sense of civic responsibility, mean very little to him. He thinks of peace as that boring and meaningless interlude between wars, of democracy as a weak and corrupt substitute for autocracy" (p.56). In Mustapha's opinion, "the best ruler is a benevolent tyrant" (p.56).

Also, Mustapha is cautious and watchful regarding his property; he is well aware of the fact that the concept of property and ownership is respected very loosely in his neighborhood. If a wind accidentally takes away his clothes from the balcony and carries it all the way into the neighbor's courtyard, there is a high chance that the neighbor takes the item for good, and the possibility of retrieving the lost article is reduced to a minimum. The lack of mental security regarding ownership has led to a deep-seated mistrust in Mustapha's approach towards his acquaintances; this "ever-present distrust" even exists at home where he locks away his clothing "for fear the other members of the family may steal it and sell it" (p.59). Thus, to protect his property and to reduce his financial loss, Mustapha has learned to develop a vigilant and hostile persona by having "this constant suspicion" of others and openly expressing "hostility to everyone" wherever and whenever he sees fit (p.59).

There are several other features that Bowles ascribes to Mustapha's persona; perhaps some of these interesting features can be seen below:

Premeditated murder is extremely rare, and so-called sex maniacs are unknown [in Mustapha's neighborhood]. Perhaps this is because Mustapha, not being well-versed in the art of self-control, nor even, doubtless, able to see any particular virtue in it, is inclined to do what he feels like doing at any given moment, and thus remains relatively unrepressed. His enthusiasms and rages are likely to be short-lived. (pp.59-60)

Mustapha's behavior does not go hand-in-hand with how a tactician may approach life's affairs. Mustapha does not follow a carefully planned strategy to achieve a specific end. He approaches life with a code of conduct that his passions and desires should not be "repressed" at any given time, but it does not mean that the emotional or physical needs may linger there forever. On the contrary, once the needs are met, he may lose interest radically; this means that incidents such as murder, rape, and child abuse do happen in Mustapha's vicinity, but it is more or less incited by unpredetermined incentives rather than the carefully formulated preparations.

It is no big deal to Mustapha when he pokes his nose into other peoples' lives, but when his turn comes, he becomes rigorously secretive and reticent; as a result, he has developed two major strategies to dodge the inquirer's questions while maintaining his enigmatic image in the neighborhood. The primary plan is to avoid uttering what comes to his mind; he often conceals his true thoughts and opinions in conversations. "For, according to his devious reasoning, if he were to utter his true thoughts, he would be giving himself away, playing recklessly into your hands. Thus it is extremely important for him to make conversation which will lead you away 
from, rather than toward, whatever is in his mind" (p.6o). And if he sees that he is failing to distract the inquirer's attention, Mustapha comfortably shifts to the second strategy, which is basically lying or falsehood. It never occurs to him that by lying "he may risk losing your respect ... because he assumes that you would naturally like to be as accomplished a liar as he [is]" (p.61).

Last but not least is Mustapha's observational power. He is described to have an "acute" observation ability; he is alert and "his sense-impressions ... are intense; he is very conscious of smell, color, sound and texture ... He can spend hours merely sitting on the ground, looking out over a landscape, in a kind of contemplation that you and I will never know." (p.68)

Many North African characters in The Delicate Prey are modeled after Mustapha; miscreants like the infamous people of the Reguibat, the notorious Moungari, Jacinto, Amar, Mokhtar, and many more share similar traits. Even a non-African character like Chaliá Sanchez is capable of stinging others with a hostile attitude continually. In this regard, even Smail, the Arab souteneur in The Sheltering Sky, Grove Soto, the enigmatic antagonist in Up Above the World, and Qaouaji, the café worker in "A Distant Episode," should not go unnoticed. Combining the readings of the two passages, "By the Water" and "Mustapha and His Friends," we arrive at a particular type of character which is not highly refined or fully developed by the author. Bowles does not offer sufficient or any background information on the characters, and yet he does not even develop them during the narratives. Despite being too static and flat, still, the reasons or motives behind the characters' actions might be difficult to decipher. Perhaps this inexplicability is due to the unpredictable nature emanating from the characters' unruliness.

Searching for the motive behind the actions of the people of the Reguibat in "A Distant Episode," Eric Mottram finds their motivation "beyond reason and reasoned irrationality" (Mottram, 1982, P.18). Mottram reiterates on the fact that the motive behind the Reguibat's violence is unexplainable. Still, he also brings the new paradoxical term, 'reasoned irrationality,' into the light, which can give a new dimension to our discussion. I reckon 'reasoned irrationality' is similar to what Samuel Taylor Coleridge stated about Iago, the antagonist of William Shakespeare's Othello. In his reading of the play, Coleridge addressed the problematic issue of Iago's motive and the nature of his viciousness towards the moor. In Coleridge's view, Iago's actions were driven by a sense of "motiveless malignity." I would like to suggest a parallel reading of the motive behind Bowles' villains based on Coleridge's "motiveless malignity" to define how the motive should be addressed regarding Bowles' characters.

\subsection{Motiveless Malignity}

The notion of a typical villain in Bowles follows an older literary tradition of motiveless ill-will; this pattern has often been traced back to William Shakespeare's well-known tragedy, Othello (1604), where Iago, the antagonist, loathes the protagonist of the play with no specific reason. Two centuries later, Samuel Taylor Coleridge coined the term "motiveless malignity," when he gave a lecture on the play in winter of 1818 :

The last Speech [1.3.381-403], the motive-hunting of motiveless malignity - how awful! In itself fiendish - while yet he was allowed to bear the divine image, too fiendish for his own steady view. - A being next to Devil - only not quite Devil - \& this Shakespear has attempted - executed - without disgust, without Scandal! (Cited in Foakes, 1989, 113)

Coleridge puts forward this fact that there is no distinct and coherent logic behind Iago's enmity. "Iago's villainy lacks a clear motive, but [it] arises from sheer delight in the suffering of others. 
This makes Iago 'fiendish' like the 'devil', yet disconcertingly human" ("Coleridge's annotated copy of Shakespeare," n.d.). In addition, the objective and impersonal portrayal of Iago seemed to aggrandize the devilish representation of the character. Then, In Omniana, a collection gathered by Robert Southey, Coleridge explains what he means by "motiveless malignity." He gives a more vivid account of the nature of Iago's hatred towards Othello and Cassio, and defines how the antagonist's motive should be seen and regarded:

It is a matter of infinite difficulty, but fortunately of comparative indifference, to determine what a man's motive may have been for this or that particular action. Rather seek to learn what his objects in general are!-What does he habitually wish? habitually pursue? - and thence deduce his impulses, which are commonly the true efficient causes of men's conduct; and without which the motive itself would not have become a motive. [...] Without the perception of this truth, it is impossible to understand the character of Iago, who is represented as now assigning one, and then another, and again a third, motive for his conduct, all alike the mere fictions of his own restless nature, distempered by a keen sense of his intellectual superiority, and haunted by the love of exerting power, on those especially who are his superiors in practical and moral excellence. (Coleridge, 1995, p.310)

Coleridge argues that it is almost impossible to discern the motive of a wicked character like Iago because he is driven by a "restless nature" which will not be quietened until it subdues the rival. However, in the case of Iago, the rival is absent, and the competition seems not to exist. Therefore, Iago, who has the "love of exerting power," selects or invents adversaries from the upper social class, and searches for motives not only to justify his malicious "conduct" but also to subdue his superiors and satisfy his thirst for triumph. "In other words, Iago is trying to find for his cussedness a reason-which does not [even] exist" (Rand, 1950, p.157). And it is apparent that the villain is in a constant struggle to find a motive for his motiveless malignity.

The meaningless enmity observed in Othello is similar to what we see in Bowles' "At Paso Rojo," where Chaliá Sanchez, a middle-aged unmarried heiress, holds an unreasonable grudge against one of the workers, Roberto, and frames him for a theft which he did not commit. After Don Federico, the landowner, dismisses Roberto due to the alleged theft, Chaliá, who hitherto was suffering from an insomniac type of disorder seems to be mollified "and [goes] peacefully to sleep, thinking of how surprisingly little time it [has] taken her to get used to life at Paso Rojo, and even, she [has] to admit now, to begin to enjoy it" (At Paso Rojo, p.76).

Furthermore, Rand's assertion about Iago's "restless nature" evokes many Jungle Paintings by the post-impressionist painter Henry Rousseau, the paragon of which can be found in Tiger in a Tropical Storm or Surprised! (1891), where a crouching tiger, in the midst of a ghastly rainforest, stares at an unknown object alertly and belligerently. The primitive look at art in Rousseau is close to what we see in The Delicate Prey. Rousseau's dense and mysterious tropical jungles evoke gruesome feelings in the viewer's eyes; as in Bowles, the barren terrain induces similar effects. Like the subjects of Rousseau's paintings, Bowles' villains are vigilant and combative; they clutch every opportunity which is thrown at them in the Sahara. And like Shakespeare's Iago, they are so perverse that they cannot be reasoned with. Amy Schwartz writes that Iago's persuasive force does not depend on outside factors, it rather comes from the "evil inside human beings-the thing itself and not how it got there" (Schwartz, 1989). Bowles' tales follow the same tradition. The narrator in The Delicate Prey does not deliberate on how the evil got within the villain's skin; he rather addresses the evil itself. In this light, the villains should be regarded as belligerent opportunists, lurking at every corner, waiting for the right moment to pounce on their preys. 
Bowles describes Jacinto, one of his fictional culprits as follows: "Jacinto was used to waiting" (Under the Sky, p.57). Thus, the motive should not be viewed as a "single conscious determining thought" channeled towards a particular object; it should rather be viewed as "the whole being moving in a certain direction at a particular moment" (Badawi, 1973, p.114). The critic who fails to interpret the motive first and foremost forgets to notice the character himself, his ambition, and his vicious pledge for oppressing and triumph.

The flat, oppressive, non-negotiating, vigilant, and static villains, who do not care much about social laws and rules, occupy a considerable space of Bowles' fictive universe. What Bowles does in his fiction is to let loose a proactive villain on the map and avoids providing enough background information on the character. The writer also refuses to develop the villain during the narrative-even when the character becomes the protagonist-and does not assign a particular motive for the character's unreasonable attitude towards other human beings. The question is that why a flat character whose aspirations are not driven by morality, uprightness, and kindness (those social virtues which we usually praise in reality and fiction) is given such privilege to become the central figure in many Bowles' stories? What can this type of character bring to the table for Bowles? To answer these questions, first, we have to discuss what kind of things these types of characters are capable of doing.

\subsection{Bowles' Villain and Violence}

Bowles' unbending villains have distinctive characteristics. Given the fact that no particular motive(s) is assigned to them, they have become unwonted and unpredictable. It is clear that in the end, the antagonists want to profit from the looted goods, but it does not seem that the rapine is the prime motive to perpetrate violence. For instance, in "The Delicate Prey," Moungari's brutality comes from a longtime animosity between his tribe and the Filala's. It does not occur to the reader that the Moungari commits violence chiefly to take possession of the Filala's leather merchandise; his paramount wishes are to oppress, torture, rape, and above all, deride his sworn enemies. Thus, the leather goods provide him with sufficient motive to take out his anger on the Filala. This motive-hunting attitude, combined with the unpredictable nature, gives a fiendish aura to Bowles' villain. In this respect, Bowles' villain sharply differs from Bulgakov's Woland, the foreign professor of black magic in The Master and Margarita. Unlike Woland, the antagonist in Bowles is not a mastermind and a glib-tongued devil, and unlike Alex, the notorious gang leader of Burgess' A Clockwork Orange, Bowles' villain is not loquacious and flamboyant in committing violence. On the contrary, Bowles' antagonist is untalkative and tries to avoid conversation with his target; instead, he prefers to remain silent and meditate on the surroundings.

The villain in Bowles also has a primitive approach towards the subject of violence; he uses force to enslave and subdue the victim to satisfy his fleeting wishes anywhere at any given moment. And to achieve this aim, he employs a mixture of violence and a non-negotiating approach. The artistry of Bowles comes into the picture when in "A Distant Episode," the author assigns the task of buying "a camel-udder box" to a western linguist who specializes in different dialects spoken in North Africa. The linguist is "making a survey of variations on Moghrebi" (A Distant Episode, p.25) when he faces the Reguibat, the nomad tribe of Morocco and Algeria. The professor, who hitherto traveled to those regions, seems not to lack confidence in communicating with the tribe; hence he believes he could easily strike a deal for a camel-udder box, unaware that he is throwing himself into imminent danger. The below passage describes the professor's first encounter with the people of the Reguibat: 
Two snarling dogs came running from behind the oncoming men and threw themselves at his legs. He [the professor] was scandalized to note that no one paid any attention to this breach of etiquette. The gun pushed him harder as he tried to sidestep the animals' noisy assault. Again he cried: "The dogs! Take them away!" The gun shoved him forward with great force and he fell, almost at the feet of the crowd of men facing him. The dogs were wrenching at his hands and arms. A boot kicked them aside, yelping, and then with increased vigor it kicked the professor in the hip. (A Distant Episode, p.31)

The violence depicted here shows that the tribe do not care about humane behavior. What makes the tribe's action unorthodox or meaningless is the fact that the Reguibat do not want to communicate with the potential buyer, and unknowingly they are throwing away a potential longtime partnership. They do not even want to know the professor and his purpose of wandering in their territory. Once the Reguibat catch sight of the stranger, they unleash their ferocious dogs to welcome him with brutal and continuous attacks. Perhaps that is the reason why Gomes believes that "in the relationship between colonizer and colonized, there has been a complete role reversal with the ascendency of the colonized" (63). And this happens because Bowles' violence comes so unpredictable that it muddles the westerners (the colonizers), transfixes them, and makes them unable to think. But why does the author stress (motiveless, meaningless) violence? What is Bowles' view of violence? And what role does violence play in Bowles' fiction?

\subsection{Beyond Bowles' Violence}

In one of the interviews in 1981, Jeffrey Bailey asks the writer why all the characters in The Delicate Prey "were victimized by either physical or psychological violence?" Bowles acknowledges that most of the characters in the collection are somehow touched or affected by senseless violence:

The violence served a therapeutic purpose. It's unsettling to think that at any moment life can flare up into senseless violence. But it can and does, and people need to be ready for it. What you make for others is first of all what you make for yourself ... The process of life presupposes violence, in the plant world the same as the animal world. But among the animals only man can conceptualize violence. Only man can enjoy the idea of destruction. (Bailey, 1993, p.122)

Two distinctive features are attributed to violence in Bowles' response; the first one is the therapeutic effect of violence, or what I regard as violence therapy, and the second is a degree of enjoyment in the thought of destruction. The therapeutic effect can work at different levels: on the surface, it can be regarded as a peculiar form of treatment that helps the assailant to stabilize his psychological unrest. For instance, In "A Thousand Days for Mokhtar," Mokhtar, who patently suffers from a mental problem, finds his remedy in the act of aggression against one of the locals. In the end, he is able to recover his peace of mind through perpetrating violence: "His mind no longer dwelled upon the earlier happy hours of his life, because the present hours were happy ones as well" (A Thousand Days for Mokhtar, p.302). However, in a more profound sense, the therapeutic effect can mean the estrangement and alienation of the self on the side of the victim.

In his Book Deadly Musings, Michael Kowalewski argues that the "lack of motive forms only one component of a larger absence, one that might more precisely be termed 'contextless,' 'uninterpretable,' 'unaccommodated,' 'unintelligible,' perhaps even 'selfless'” (Kowalewski, 1993, p.14). By stripping off violence from its common component (motive), the act of violence, and the meaning behind it become incomprehensible for the victim. This lack of understanding leads to a 
degree of estrangement, where the victim is compelled to come to new terms with an undefined universe and therefore try to alter his outlook to fit in the unexplored. Again, "A Distant Episode" is the beau idéal of such an estrangement case, where Bowles' linguist forces himself not to 'think' (which is perhaps the most distinctive feature of human beings). After being tormented and enslaved by the Reguibat, the professor refuses to exercise his mental faculties due to the fact that a conscious existence could only bring him pain. He chooses to stay consciousness-less and act like a cymbal-banging monkey instead:

Even when all his wounds had healed and he felt no more pain, the Professor did not begin to think again; he ate and defecated, and he danced when he was bidden, a senseless hopping up and down that delighted the children, principally because of the wonderful jangling racket it made. And he generally slept through the heat of the day, in among the camels. (A Distant Episode, p.32)

As Tanner asserts, violence has this “capacity to destroy not only the form of the victim's body but the familiar forms of understanding through which that victim constructs him-or herself as subject" (Tanner, 1994, p.4). It is evident why violence is developed to be the primary constituent of Bowles' tales as it has the power to defamiliarize the familiar. Also, Morocco becomes the primary setting of Bowles' stories because, according to Pounds, "Bowles seems to have found in [...] Morocco a framework of ritual and tradition in which violence and extreme states of mind form an integral part" (Pounds, 1986, p.436). Therefore, the meaningless violence in The Delicate Prey serves as a medium for the author's creational purposes and an estrangement apparatus on the side of the victim as well.

As part of his fiction writing technique, Bowles dissociates motive from violence and concentrates on the sheer violence to magnify this leitmotif. But Bowles' preoccupation with this motif does not end only on the conceptual level. This idée fixe is also manifested in the author's writing style. In the following section, I discuss Bowles' writing style and his strategy for depicting violence.

\subsection{Detached Narration Technique}

In an interview in 1996, Florian Vetsch asks Bowles about the relationship with his longtime mentor, Gertrude Stein. There is an interesting section in the conversation where Bowles discusses the influence of Stein on his writing technique:

Florian Vetsch: On which parts of your work did she [Stein] have an influence?

Paul Bowles: Well, I learned to admire simplicity in language from her, to cut all unnecessary words out, throw them. The important thing is that the words tell what you want to know, but not how it made you feel.

FV: So her influence has got to do with objectivity.

PB: Yes ... You know, I was very much against the idea of describing how I felt. I don't think it's a good idea. The reader can tell how you felt the way you describe what you saw, what happened. Then you don't say, it made me feel sad or I was delighted. No, no.

FV: So you don't let feelings influence your style.

PB: No, no. I try to keep them out.

FV: A lack of emotion? 
PB: Yes, or a lack of showing emotion, yes. There's nothing wrong with feeling emotion, but there is no point in writing about it or letting it influence your style. No. (Vetsch, 1996, p.645)

In the above conversation, Bowles specifies the three key factors which mold his writing style: Simplicity, objectivity, and emotionlessness. It means that the author tries to detach himself as the narrator and edge closer to an observatorial role. This technique gives an aura of reality to the work of fiction and intensifies the horror of a torture scene. Sawyer-Lauçanno postulates that the detached writing style in depicting violence is a part of Bowles' narrative design, as the author "rarely indulges" the narratives "in sensational description nor attempts to demonstrate through a plethora of adjectives how horrible a torture" can be. "Instead, [...] he simply relates the facts, as if he were describing the most mundane matter, thus immeasurably increasing the impact." (Sawyer-Laucanno, 1999, p.279).

Bowles usually avoids intervention as the narrator when describing brutality. He avoids using copious adjectives and does not interrupt the narratorial flow by a comment or an emotional remark; instead, the writer narrates the story as if he is explaining the most routine matter. But Bowles' writing technique does not end with a cold and apathetic tone. In addition to the emotional detachment, Bowles uses a direct and straightforward language where perhaps directness is the last thing to look for. It seems that the more hostile the narrative gets, the franker the narratorial language becomes. Gilbert Sorrentino writes: "The language of Bowles' fiction is reticent and formal, but often brutal in its flat candor" (Sorrentino, 1981). So, in addition to a detached narration, Bowles tries to have a certain frankness in his language in describing the violent act. Perhaps the torture scene in "The Delicate Prey" is a fitting example of Bowles' detached and frank way of depicting violence where the Moungari overpowers Driss, the young Filali:

The man moved and surveyed the young body lying on the stones. He ran his finger along the razor's blade; a pleasant excitement took possession of him. He stepped over, looked down, and saw the sex that sprouted from the base of the belly. Not entirely conscious of what he was doing, he took it in one hand and brought his other arm down with the motion of a reaper wielding a sickle. It was swiftly severed. A round, dark hole was left, flush with the skin; he stared a moment, blankly. Driss was screaming. The muscles all over his body stood out, moved. Slowly the Moungari smiled, showing his teeth. He put his hand on the hard belly and smoothed the skin. Then he made a small vertical incision there, and using both hands, studiously stuffed the loose organ in until it disappeared. (The Delicate Prey, p.168)

Such gut-wrenching descriptions are frequent in "The Delicate Prey." Here is another instance of the same story which describes a murder: "At dawn he awoke and reached for his razor, lying on the ground nearby. Driss moaned faintly. The Moungari turned him over and pushed the blade back and forth with a sawing motion into his neck until he was certain he had severed the windpipe" (The Delicate Prey, p.168). Reading Bowles sometimes instills the idea that a wildlife documentary is being recorded, perhaps of the kind in which a predator ensnares a prey. The one who records the scene may feel sympathy for the prey, but he refuses to intervene because he does not want to meddle with the work of nature. This detached way of recording things also evokes a sense of ineluctability as if the characters are doomed by cursed kismet, and no escape from the plight is on the horizon. As Reese posits: "the cool, detached clarity of Bowles' prose lends the events" a clear "sense of coherence and inevitability" (Reese, 2013, p.9). 
But aside from the feeling of sympathy for the prey (which apparently Bowles does not have), there is also a feeling of excitement in watching a wildlife run-and-chase; and that is what Bowles considered as the "enjoyment" in the thought of destruction. I refer to "A Thousand Days for Mokhtar" as an example where Mokhtar enjoys his own anger, and the horrified expression on Bouchta's face: "He was enjoying his own anger and the sight of Bouchta as he became the victim of such a senseless rage" (A Thousand Days for Mokhtar, p.301). Here, I want to draw a distinction between the violence which Bouchta, as the victim, experiences, and the violence that we, as the readers, experience; because even though the act of violence is the same, it produces different effects on the victim and the observer. In the last section, I will discuss the impact of Bowles' violence on the reader and the aesthetic capacities that the sheer depiction of violence can bring to the narrative.

\subsection{Aestheticizing Violence}

In the introductory part of his book, The Aesthetics of Murder, Joel Black discusses that only the victim of a violent incident deals with the bitter reality of the brutal experience, and the term "reality" means something else for the observers or the readers of violence:

Once we recognize the peculiar inception of the word aesthetic in the English language, and begin to appreciate the problematic role that aesthetics has come to play in Western philosophy and culture in general, we may begin to sense-although not without resistance- the extent to which our customary experience of murder and other forms of violence is primarily aesthetic, rather than moral, physical, natural or whatever term we choose as a synonym for the word real. Only the victim knows the brutal "reality" of murder; the rest of us view it at a distance, often as rapt onlookers who regard its "reality" as a peak aesthetic experience. (Black, 1991, P.3)

According to Joel Black, we, as the mere viewers of a brutal incident, would experience different sensations from those who are involved with the violence itself. Black believes that the spectators are involved in an aesthetic experience primarily. But, the word "aesthetic" is subjected to many interpretations as it can still be placed among the most ambiguous terms in the discussions of art and literature. What I mean by an aesthetic experience is very close to Slobodan Marković's definition of the concept. In his essay, "components of aesthetic experience," Marković argues that aesthetic experience is "an exceptional state of mind which is qualitatively different from 'normal' everyday mental states. In this mental state, a person is fascinated with a particular object, whereas the surrounding environment is shadowed," and "self-awareness is reduced" (Marković, 2012, p.12).

Marković's definition of aesthetic experience is parallel to Viktor Shklovsky's concept of ostranenie in art. Shklovsky believes that the cognitive processes of observing and perceiving have aesthetic dimensions and it is the artist's duty to exploit different techniques in order to prolong the viewer's [reader's] cognitive process to achieve an aesthetic end: "The technique of art is to make objects 'unfamiliar' [...] to increase the [...] length of perception because the process of perception is an aesthetic end in itself and must be prolonged" (Shklovsky, 1917, p.16). And in this regard, the excessive occurrences of violence in Bowles, his reticent and motiveless villains, and the author's detached narration are combined to serve one primary purpose: To distance the observer from the ordinary and everyday notion of violence and to present violence as a source of literary excitement. Richard F. Patteson contends: "Here in The Delicate Prey it is essential to Bowles' creative purpose, which is to find an intelligible dramatic form for an outsideness so 
absolute as to be quite beyond ordinary human comprehension" (Patteson, 1987, p.4). Therefore, the senseless or the contextless violence plays an important role as it is used as a stimulator of the estrangement to prolong the process of perception for the reader. In Robert Stone's words, "Bowles's enthusiasts are glad to trade sympathy for the absence of ordinariness" (ix, 2001, Stone).

Michael Spindler postulates that even the recurrent motif of "travel" in Bowles is employed to produce estrangement: "In Bowles' bleak world, travelling ... act[s] as a prism breaking up the harmonious illusions of the familiar" (Spindler, 1989, p.37). It is why Bowles tends to select his protagonists from the travelers and wanderers of the world. The writer often emphasizes that his characters should not be viewed as mere tourists or sightseers; the most prominent example is, without doubt, Porter Moresby's notion of himself: "He did not think of himself as a tourist; he was a traveler" (The Sheltering Sky, p.6). "Travel" or the concept of traveling has the capacity to expose the travelers to unknown regions and cultures, and once the unfamiliar is unveiled, the preconceived familiar cracks gradually.

The Delicate Prey and Other Stories, in my estimation, is the peak of Bowles' artistic and creative formula where the author partners up with a motiveless villain and lets him loose on North African terrains to see how the villain inflicts harm upon an ill-fated character. The author assigns several assets to this villain, and thus the villain is capable of inflicting injury anytime and anywhere. In some instances, he commits the highest possible brutality on the victim. And in order to treat the subject of violence aesthetically, Bowles detaches the violent act from its integrated component, motive. It should be noted that the literary inclination towards aestheticizing violence, or the aesthetic based on violence, is not limited to Bowles; it cannot be assumed as something unprecedented, as it became a vogue for many other fiction writers of the twentieth century. From the early decades of the twentieth century towards its middle, there was "a mounting interest in, and commitment to, a modernist aesthetic based on violence, antagonism and upheaval [...]. The association with detachment, emotional reserve and intransigent artistic practices indicates, in short, that the modernist aesthetic has a strand of compulsive belligerence woven into its DNA" (Sheehan, 2013, pp. 2-3). The term "compulsive belligerence" may be well suited to the works of such authors like Burgess, Vonnegut, Orwell, and Bowles; however, regarding the motive and the subject matter, there is a considerable difference between Bowles and his contemporaries.

\section{Acknowledgments}

I would like to thank Prof. Dr. Dietmar Schloss (the professor of American literature and culture at the English Department of Heidelberg University, Germany) for the revisions and suggestions that he made on the original manuscript. I am also grateful to Sebastian Tants (the doctoral

candidate at The Heidelberg Center for American Studies, Heidelberg University, Germany) for his insightful remarks on the second draft of this paper.

\section{References}

Badawi, M. (1973). Coleridge: Critic of Shakespeare. Cambridge: Cambridge University Press.

Bailey, J. (1993). The Art of Fiction LXVII: Paul Bowles. In G. Caponi, Conversations with Paul Bowles (Literary Conversations Series) (1st ed., pp. 111-134). Jackson: University Press of Mississippi. 
Black, J. (1991). The Aesthetics of Murder: A Study in Romantic Literature and Contemporary Culture (Parallax: Re-visions of Culture and Society). Baltimore, Md: Johns Hopkins University Press.

Bowles, P. (2001). A Delicate Prey. In The Stories of Paul Bowles (1st ed., pp. 162-170). New York: Ecco.

Bowles, P. (2001). A Distant Episode. In The Stories of Paul Bowles (1st ed., pp. 24-35). New York: Ecco.

Bowles, P. (2001). A Thousand Days for Mokhtar. In The Stories of Paul Bowles (1st ed., pp. 297-303). New York: Ecco.

Bowles, P. (2001). At Paso Rojo. In The Stories of Paul Bowles (1st ed., pp. 6o-76). New York: Ecco.

Bowles, P. (2001). By the Water. In The Stories of Paul Bowles (1st ed., pp. 1-8). New York: Ecco.

Bowles, P. (2006). Mustapha and His Friends. In Their Heads Are Green and Their Hands Are Blue: Scenes from the Non-Christian World (pp. 55-76). Harper Perennial.

Bowles, P. (2001). Tea on the Mountain. In The Stories of Paul Bowles (1st ed., pp. 128-139). New York: Ecco.

Bowles, P. (2002). The sheltering sky. New York: Ecco.

Bowles, P. (2001). Under the Sky. In The Stories of Paul Bowles (1st ed., pp. 53-59). New York: Ecco.

Bowles, P. (2006). Without Stopping. New York: Harper Perennial.

Coleridge, S. (1995). Motives and Impulses. In H. Jackson \& J. Jackson, The Collected Works of Samuel Taylor Coleridge, Volume 11: Shorter Works and Fragments (Volume 1) (1st ed.). Princeton: Princeton University Press.

Coleridge's annotated copy of Shakespeare. Retrieved from https://www.bl.uk/collection-items/coleridgesannotated-copy-of-shakespeare.

Foakes, R. (1989). Coleridge's criticism of Shakespeare. London: Athlone.

Finlayson, I. (2015). Tangier: City of the Dream. Norwich: Tauris Parke Paperbacks.

Gomes, F. (2012). Paul Bowles's First Insight into the Interaction with North African Alterity in "Tea on the Mountain." Mediterranean Studies, 20(1), 59-70.

Hassan, I. (1989). Paul Bowles: The Imagination of Exile. In Selves at Risk: Patterns of Quest in Contemporary American Letters (Wisconsin Project on American Writers) (1st ed., pp. 135-155). Madison: University of Wisconsin Press.

Jackson, C. (1950, December 9). The Delicate Prey [Review]. The New Yorker, 167-168.

Kowalewski, M. (1993). Deadly Musings: Violence and Verbal Form in American Fiction. Princeton: Princeton University Press.

Lesser, W. (1986). Murder as Social Impropriety: Paul Bowles's "Evil Heroes". Twentieth Century Literature, 32(3/4, Paul Bowles Issue), 402-407.

Marković, S. (2012). Components of aesthetic experience: aesthetic fascination, aesthetic appraisal, and aesthetic emotion. i-Perception, 3(1), 1-17.

Mottram, E. (1982). Paul Bowles: Staticity \& Terror. The Review of Contemporary Fiction, 2(3), 6-30.

O'Connor, W. (1959). The Grotesque in Modern American Fiction. College English, 20(7), 342-346.

Patteson, R. (1987). A World Outside: The Fiction of Paul Bowles. Austin, University of Texas Press.

Pounds, W. (1981). Paul Bowles and The Delicate Prey. The psychology of predation. Revue Belge De Philologie Et D'histoire, 59(3), 620-633.

Pounds, W. (1986). Paul Bowles and Edgar Allan Poe: The Disintegration of the Personality. Twentieth Century Literature, 32(3/4, Paul Bowles Issue), 424-439. 
Rand, F. (1950). The Over Garrulous Iago. Shakespeare Quarterly, 1(3), 154-161.

Reese, S. (2013). 'My work has nothing to do with surrealism': Paul Bowles, View and the Surreal Short Story. Surrealism Summer, 10, 1-19.

Sawyer-Lauçanno, C. (1989). An invisible spectator. New York: Grove Press.

Schwartz, A. (1989). 'MOTIVELESS MALIGNITY'. Retrieved from https://www.washingtonpost.com/archive/opinions/1989/05/16/motiveless-malignity/oebec6dcd299-4b4d-89b6-e7f495cfod4e/?utm_term=.aeb5cfd3dc5b

Sheehan, P. (2013). "Modernism's Blasted History". Modernism and The Aesthetics of Violence, Cambridge University Press, 1-21.

Shklovsky, V. (1917). Art as Technique. In J. Rivkin \& M. Ryan (Eds.), Literary Theory: An Anthology (2nd ed., pp. 15-21). Blackwell.

Sorrentino, G. (1981). Paul Bowles: The Clash of Cultures. Retrieved from https://www.washingtonpost.com/archive/entertainment/books/1981/o8/o2/paul-bowles-theclash-of-cultures/e4bboa98-6637-4615-af97-63b66f8e4120/?utm_term=.a173eg1be5f8

Spindler, M. (1989). The Prism of Estrangement: Placing the Fiction of Paul Bowles. Australasian Journal of American Studies, 8(1), 35-45.

Stone, R. (2001). Introduction. In P. Bowles, The Stories of Paul Bowles (1st ed., p. ix-xii). New York: Ecco.

Tanner, L. (1994). Intimate Violence: Reading Rape and Torture in Twentieth-Century Fiction. Indianapolis: Indiana University Press.

Vetsch, F. (1996). Desultory Correspondence: An Interview with Paul Bowles on Gertrude Stein. MFS Modern Fiction Studies, 42(3), 627-645.

Walonen, M. (2011). Writing Tangier in the Postcolonial Transition: Space and Power in Expatriate and North African Literature. Ashgate Publishing Group.

White, E. (2004). Paul Bowles. Arts and Letters (pp. 91-99). San Fransico: Cleis Press Inc. 